\title{
The Ignored Religious Other: Atheist/Agnostic Pre-Service Teachers
}

\section{Dr. Derek Anderson, Associate Professor}

School of Education, Leadership, and Public Service

Northern Michigan University dereande@nmu.edu

\author{
Ms. Holly Mathys, Graduate Student \\ School of Education, Leadership, and Public Service \\ Northern Michigan University \\ homathys@nmu.edu
}

Ms. Tanya Cook, Graduate Student

School of Education, Leadership, and Public Service Northern Michigan University tacook@nmu.edu

\section{Doi:10.5901/jesr.2014.v4n6p503}

\section{Abstract}

The purpose of this case study was to investigate how four American Atheist/Agnostic (A/A) elementary pre-service teachers (PSTs) planned, taught, and reflected on a world religions field experience with $7^{\text {th }}$-grade students, as well as to examine the role self- and professional-identity. Data sources included at least three interviews with each participant, lesson observations, and document analysis of their lesson plans and reflection journals. All four of the PSTs experienced discrimination and exclusion during childhood because of their lack of religiosity. The A/A PSTs desire to teach in a manner that promotes critical thinking and student interpretation of historical events, yet they are indifferent about ubiquity of religion in schools and are nervous about offending students and parents. A/A teachers are likely to feel isolated and marginalized, which are key factors in teachers leaving the profession.

Keywords: atheism, world religions, teacher education, elementary, self-identity

\section{Introduction}

The United States is a religious country by most measures. Nearly half of Americans approve of requiring the Lord's Prayer or Bible verses in public schools (ARDA, 2013). Americans put belief in God at the heart of a good, moral society (Cragun, Kosmin, Keyser, Hammer, \& Nielson, 2012; Smith, 2013). Because they reject what the vast majority of their fellow citizens hold to be true, Atheists/Agnostics (A/As) are marginalized at best, and at worst are discriminated against and distrusted outright.

The percentage of Americans who are non-religious is not clear, though it is clear that the percentage is increasing. The 2004 General Social Survey revealed that 14\% of Americans claimed no religious preference, a significant jump from previous decades (Baker \& Smith, 2009). A 2012 PEW Research Center survey showed that the number of Americans who do not identify with any religion has grown rapidly, with $20 \%$ of the US population and $34 \%$ of young adults $(<30)$ claiming no religious affiliation. It is important to note, however, that most of the "nones" claimed "nothing in particular" (13.9\%) rather than declaring "atheist" (2.4\%) or "agnostic" (3.3\%) outright.

Defining non-religion is tricky (Smith, 2013). The terms Atheist and Agnostic are generally used interchangeably (Galen, 2009), which we do in this paper, even though their constructs differ. The term "atheism" designates a lack of belief in a god(s) (Smith, 1979; Bramlett, 2012); whereas, "agnostic" refers to a lack of knowledge about god(s) (Miovic, 2004; Bramlett, 2012). Thus, one could be an agnostic atheist (thinks there is no god but cannot be certain), gnostic atheist (thinks there is no god and is certain), agnostic theist (thinks there is a god, but cannot be certain), or a gnostic theist (thinks there is a god, and is certain). Most surveys and researchers, including Pew, differentiate between atheists 
and agnostics along the popular conception that atheists do not believe in god, and that agnostics just are not sure if there is a god. It is no surprise that atheists are viewed more negatively than agnostics in America (Jacoby, 2004).

Being non-religious is a liability in the US. For example, if members of Congress were representative of the US population at large, we would expect 75 US Senators and Representatives to be non-religious; however, in 2013 only one member, Rep. Krysten Sinema, D-Arizona, declared her religious affiliation as "none" (Stedman, 2012). Even so, Sinema has rejected the atheist label. In 1987, President George H. W. Bush said, "I don't know that Atheists should be considered as citizens, nor should they be considered patriots" (Sherman, 2013, ๆ 1). While the vast majority of the "nones" are Democrats, recently, President Obama petitioned the Supreme Court to relax limits on prayer at public meetings (Savage, 2013). Religion is pervasive in American politics. What's more, there are still laws in several US states barring atheists from holding public office (Cimino \& Smith, 2007).

In addition to being underrepresented in government, nonreligious Americans are generally despised. For example, more than $60 \%$ of Americans expressed that atheists negatively influence society (Fitzgerald, 2003, as cited in Bramlett, 2012), and nearly half of Americans would disprove of their child marrying an atheist (Edgell, Gerteis, \& Hartmann, 2006). Though the Boy Scouts of America dropped its longstanding ban on homosexuals in May 2013, agnostics and atheists are still barred from participating as Scouts or Scout Leaders (www.scouting.org). Furthermore, courts have a consistent record of denying custody to A/A parents expressly because of their lack of religious belief (Cline, 2006).

Americans report greater disregard for atheists than they do toward any other religious, ethnic, or racial group (Cragun, et al., 2012; Edgell et al., 2006). A 2012 Gallop poll of Americans' voting propensities found that people were least likely for vote for a hypothetical atheist candidate, with $43 \%$ stating that they would not vote for an otherwise qualified candidate if s/he were an atheist, compared with $40 \%$ who would not vote for a Muslim and $30 \%$ who would not vote for a gay or lesbian candidate.

More than $40 \%$ of atheists have experienced discrimination within the past five years, which was correlated with the extent to which the person was "out" or public about her atheism (Hammer, Cragun, Hwang, \& Smith, 2012). Atheists most commonly experienced slander (both personally and in the media), coercion (pressure to perform religious behaviors or risk social consequences), and social ostracism (Cragun et al., 2012). A/A children and teachers are especially susceptible to these types of discrimination since most US schools tend to be Christian-centric (RibakRosenthal \& Kane, 1999).

Teachers are more religious than the population on the whole (Slater, 2008). In an extensive study tracking more than 25,000 students from high school to age 35, Kimball, Mitchell, Thorton, and Young-Demarco (2009) discovered that Education majors are the most religious students on campus: "[H]ighly religious people enter Education majors, stay in them, and become more religious" (p. 22).

The spiritual and religious lives of teachers have been studied considerably, but overwhelmingly from a proreligion perspective. In other words, we know a great deal about teachers who are religious and how their religiosity impacts their teaching practice, but we know little about teachers who are nonreligious. Scholars like James Hartwick $(2007,2009,2012)$ have written widely on the subject, including numerous recommendations to foster and support the spiritual lives of public school teachers who are religious. For example, Hartwick (2007) suggested that teacher education programs offer courses on spirituality and education. Furthermore, Hartwick recommended that public schools offer spirituality retreats as part of professional development, as well as "sacred spaces" for teachers in public schools. While Hartwick called for learning more about "how to make the classroom open and inviting to all religious and spiritual orientations" (p. 675), he makes no mention of nonreligious teachers.

Though there has been limited research on the experiences and practices of teachers of minority religions, we know virtually nothing about the practices of A/A teachers. The purpose of this paper was to investigate four A/A preservice elementary teachers (PSTS) who planned, taught, and reflected on a world religions field experience with $7^{\text {th }}$. grade students. The PSTs, two of whom self-identified as Atheists and two of who self-identified as Agnostic, were the only nonreligious students out of 22 PSTs who worked in small groups to design, teach, and assess world religions lessons as part of a program requirement during their semester prior to student teaching. In this case study investigation, we sought to learn about the A/A PSTs' backgrounds, perspectives on teaching, and experiences working with classmates and students who were predominantly Christian.

\section{Theoretical Framework}

To increase our understanding of the beliefs, experiences, and practices of the four A/A teachers, we framed our 
investigation using research on self-identity. One's identity is the answer to the question: "Who am I at this moment?" (Beijaard, Meijer, \& Verloop, 2004, p. 108). A teacher's religiosity is element of both her personal and professional identity. A teacher's professional identity is how she defines herself as a teacher internally and to others (Lasky, 2005).

Teachers' self-identities are usually studied through a socio-cultural lens, which posits: "[W]hat individuals believe, and how they think and act is always shaped by cultural, historical, and social structures" (Lasky, 2005, p. 900). Teachers' professional identity influences how they teach, how they interact with colleagues, and their commitment to the profession (Hong, 2010; Sutherland, Howard, \& Markauskaite, 2010). Identity is highly relational; how people interact with others and their environment shapes how they view themselves (Hong, 2010; Johnson, 2003).

Although teacher identity is an emerging field of research (White, 2009), little is known about A/A teachers' constructions and images of self as teachers. Teachers' identities are dynamic and are influenced by what they experience in and out of schools (Nias, 1985), by the teachers' knowledge and beliefs, as well as by the school context (Sutherland, et al., 2010). A/A teachers are at risk of identity conflict when their personal identity is not aligned with their professional identity (Wenger, 1998). Beginning teachers are already at great risk of identity conflict between the type of teaching they learned about in their university teacher education courses and the type of teaching they observe in schools (Author, 2007; Beijaard et al., 2004). Beginning A/A teachers harbor another layer of conflict based on their abnormal views of religion.

Robust professional identity is socially legitimated when a teacher's relationships, structures, and spaces align (Coldron \& Smith, 1999). Although everyone holds multiple identities, "[P]eople must feel a stable sense of self. Otherwise, individuals would experience a constant state of uncertainty or discontent" (White, 2009, p. 861). A/A teachers' lack of consistency between their personal and professional identity can be problematic because it is impossible to separate one's personal and professional identities (Ball \& Goodson, 1985; Kelchtermans, 2009).

Because A/A teachers' identities are different from the vast majority of their colleagues', we also used Becker's (1963) Labeling Theory, which posits that society negatively labels people whose beliefs or behaviors differ substantially from the norm. As such, these abnormal behaviors are considered deviant. Often, the process of excluding "outsiders" is based on moral grounds. Compared to other deviant teachers such as those with piercings or tattoos, A/A teachers are squarely in the crosshairs of "moral entrepreneurs" who often believe that discriminating against or ostracizing A/As is justified.

Becker warned that outsiders should be less concerned with the labels they are given and more concerned about the power and influence of the dominant group. Deviant groups often face discrimination, even though that discrimination is often subtle (Bramlett, 2012; Feagin \& Feagin, 1978). American Atheists may seldom face direct discrimination; however, certainly they face indirect discrimination, such as in schools with a vast majority of Christian students and teachers.

\section{Methods}

This collective case study stemmed from a larger comprehensive investigation of the religious knowledge, beliefs, and actions of 22 pre-service elementary teachers (Authors, in press). To investigate the "particularity and complexity" of the four A/A PSTs, we used case study research methods including multiple data sources with an emphasis on interpretation (Stake, 1995, p. xi).

Case studies allow for a detailed and contextual analysis (Cohen, Manion, \& Morrison, 2011). Yin (1994) asserted that one benefit of case study research is its insight into the boundaries between what is known about a phenomenon and what is not known. Several elements of case study research reveal those boundaries. When cases can be studied in real-life contexts, richer description and analyses are possible. In this study, we not only talked with the PSTs about their religious beliefs and teaching practice, we observed them in action, thus strengthening the empiricism of the study.

Because all three investigators of this study are A/As, we used both descriptive and interpretive phenomenological methods (Kleiman, 2004). We attempted to bracket our personal knowledge and experiences in order to focus on the participants' words and actions, yet our biases certainly influenced our interpretations. Our preconceptions and perceptions made it impossible to describe the phenomena without also infusing some explanation.

\subsection{Data sources and Analysis}

The identification of the four A/A PSTs for this case study came from a larger study of 22 PSTs' knowledge, beliefs, and teaching about world religions (Authors, in press). The four participants self-identified as atheists or agnostic based on 
the PEW Research Center's categories and the Santa Clara Strength of Religious Faith Questionnaire (SCSRFQ), a 10question self-report measure designed to assess respondents' strength of religious faith (Plante, 2010; Plante \& Boccaccini, 1997). (It is worth noting that although the SCSRFQ is a popular, reliable, and valid assessment usable for multiple religions, the tool is not ideal for non-religious respondents. For example, one of the questions states: "I enjoy begin around others who share my faith.")

Once we solicited the four A/A participants for further study based on their self-identification, we used multiple sources of data to increase the qualitative validity of the study. A few weeks prior to the field experience, we interviewed each participant for approximately 45 minutes, focusing primarily on the process by which their group members collaborated to develop a unit on world religions. (The PSTs, in their final semester before student teaching, are required to teach all subjects to $7^{\text {th }}$-grade students as part of a weeklong field experience. Early in the semester, the $7^{\text {th }}$-grade cooperating teachers provide the PSTs with the specific content standards they would like the PST to teach during the field experience at the end of the semester.) We reviewed their lesson plans, observed the PSTs teach lessons, and debriefed with them after the teaching episodes. The PSTs wrote reflection journals based on assigned prompts, which we also included in our data set. Furthermore, we interviewed each of the A/A participants twice more - once focusing on the world religions field experience and once focusing on their personal history regarding their religious identification and its impact on their teaching.

We began our analysis by coding the data inductively using constant comparison method (Glaser \& Strauss, 1967). We then used focused coding to array the emergent sub-codes into broader conceptual categories under which we created an additional layer of sub-codes until the data reached a point of saturation (Charmaz, 2006). Throughout the coding process, we attempted to bracket our own experiences and assumptions through reflective note-taking and regular critical conversations. In addition, we relied heavily on the participants' own words.

\section{Findings}

The multiple and thorough data sources from this collective case study produced several themes. Although the primary aim of this paper was to examine and describe how atheist pre-service teachers approach teaching, and specifically the teaching of world religions, the participants' backgrounds provide valuable insight and helped us to understand how they were shaped as teachers. Thus, we begin by describing some of the themes that emerged regarding the pre-service teachers' experiences prior to becoming a teacher. Next, we explore how the atheist pre-service teachers prepared and delivered lessons on world religions to middle-school students. Finally, we examine the role of their non-religiousness and its possible impact on how the PSTs plan to teach in their own classrooms.

\subsection{Identity}

All four participants were females in their early 20's majoring in elementary education. Beth and Ann identified as atheists; whereas, Christine and Deb originally identified as Agnostics. While all four participants explicitly stated that a deity plays no role in their lives, Christine and Deb wanted to adhere to the Agnostic label because they could not be sure god does not exist. When one of the researchers asked each if she was agnostic about unicorns since we cannot prove that unicorns do not exist, both Christine and Deb conceded the point. Yet, even when we told Christine and Deb that the term atheist refers to a lack of belief in a god, not an assertion that a deity does not exist, both were hesitant to refer to herself as an atheist because of how "it's a loaded term." Beth, who wears the atheist label openly, explained it like this:

The word atheist has such a strong, negative connotation, and only when I got to college did I actually say it. I think that is why $1 \%$ say they are atheist, because it is one thing to be one, but another to declare it. It is a big deal. It makes people uncomfortable.

Deb, who admitted to wanting to take the leap to referring to herself as an atheist, stated, "Once you call yourself atheist, that is it. I would have a hard time coming back to believing something because then I would be called a hypocrite." Christine provided a similar perspective: "It's like once you call yourself an atheist, you are closing the door to ever being religious again." Yet, when we asked how likely it was that she would ever believe in a supreme being someday, Christine replied, "very close to zero" and Deb said, "not very likely, but I can't be 100\% sure."

None of the four PSTs could be described as "new atheists", or those who share the "belief that religion should not simply be tolerated but should be countered, criticized, and exposed by rational argument wherever its influence arises" 
(Hooper, 2006, ๆ 6). Beth came the closest to being a "new atheist" stating, "I love reason and the logic behind things, and like to argue with people;" however, she also noted, "I tend to avoid arguing with people because if someone won't use science or reason but only faith, it's useless."

The other three PSTs were glaringly indifferent about others' beliefs. Like Beth, each of the other PSTs noted how they use evidence, logic, and reasoning to view the world. For example, Christine said:

If you just take a step back and look at the idea of one god being the right god who wrote this archaic book that people are supposed to follow today, it is simply ridiculous. There is no credible evidence for it.

Yet, when we asked how she interacts with people who believe in god, she replied, "That's their personal belief, and I don't want to tell them that I think they're wrong. Similarly, Deb explained how she uses critical thinking more often than most people: "I am more reflective than others are. Most people don't think about what they believe or why; they just believe what they were taught." Deb also did not fit the "new atheist" definition of someone who argues against and criticizes religious belief: "I stay away from discussing religion with people. It's not my job to expose them to how illogical it all is."

\subsection{Discrimination}

Each of the PSTs described as having been teased and discriminated against for being nonreligious. Their negative middle and high school experiences help to explain why they tended to be hesitant to make their atheism/agnosticism public while in college. Ann described how she was tormented for being an atheist while attending Department of Defense school in Germany: "They called me Nazi and put death threats under my door." Beth, who grew up in a rural community with a high population of adherents to a strict denomination of Lutheranism, told several stories of how she was discriminated against for her atheism. She was regularly told by her classmates that she was going to "die a fiery death" for such infractions such as not being baptized, piercing her ears, and not attending church.

Their discrimination came primarily from peers -- three of the four PSTs described how they lost friends when they let it known that they did not believe in god; however, the PSTs also divulged how some of their teachers were overt in their discrimination. Beth told of how her middle-school science teacher dismissed evolution and would "regularly ask students to raise their hands if they went to church last Sunday." Deb noted that the tension from peers was manageable because, "kids are able to hang around with those like you, but you're stuck with your teachers."

Perhaps because of their desire to be like everyone else, all of the PSTs expressed how they wished they could believe. For example, Beth stated, "I really wish I could buy-into religion. It would be so much easier." Deb explained how she had tried praying and hoped it would provide her with strength, but knew "praying just doesn't work." Notably, three of the PSTs expressed explicitly that they are jealous of those who can believe in god.

\subsection{World Religions Field Experience - Planning}

The four PSTs were randomly assigned to seven groups of four teachers who planned for and taught lessons in all subjects to $7^{\text {th }}$-grade students for one week. Deb and Christine were assigned to the same group. Consistent with our experiences with this assignment from previous semesters, when the PSTs were given other content standards, the PSTs squabbled over what specifically to teach about each standard and how. For example, Ann described how she wanted to make sure that they covered the Protestant Reformation, but her "group members said they didn't have time or think it was important." All of the groups wanted to teach one lesson on each of the five religions, but Beth was able to convince her group to take a holistic approach: "I felt we should look at it more collectively. I thought we could look at the different topics and compare and contrast it. I won. I pleaded my case that religions are all intertwined. Why separate them into different days?"

The four nonreligious PSTs each described how they were more aware of the potential to offend students. For example, Deb noted how she warned her group members not to say things like, "We believe ..." Yet, Deb regrettably failed to discourage her group members from doing skits on Buddhism, recognizing, "[It] would never have been OK if a group did skit about Christianity." Afterward when her group debriefed the lesson, Deb was unable to get her group members to see how the skits could have been offensive to Buddhists. Beth explained how she repeatedly encouraged her fellow group members to teach all religions the same. She told them, "If you wouldn't teach a lesson that way for each of the religions, then don't do it."

In general, all the PSTs were concerned about bias and articulated that they wanted to stick to the facts. Ironically, 
the four nonreligious PSTs sought to focus less on facts and more on the complexities of world religions. For example, Ann recognized the dangers of teachers generalizing the beliefs and behaviors of all people from a particular religion: "I wanted to show that even within each religion, this is what some people believe, but some didn't and thought different things."

The PSTs expressed how, compared to their religious classmates, they wanted to encourage their students to make connections on their own, particularly from religious documents. Deb described how her fellow PSTs "just did PowerPoints and gave facts;" whereas, Christine and her "wanted to be more hands on and have kids make their own conclusions."

\subsection{World Religions Field Experience - Teaching}

In addition to watching the four A/A PSTs teach their lessons on world religions, we were able to watch most of the other PSTs teach their lessons as well. As such, we were able to look for differences between how the nonreligious PSTs taught compared to their religious peers. Though we did not attempt to quantify these differences, it appeared that the nonreligious PSTs interacted with the students differently, particularly since many of the other PSTs displayed a blatant Christian bias in their teaching, which we explored in another paper (Author, 2013). We will describe each of four nonreligious PSTs' lessons briefly here.

\subsubsection{Ann}

Ann's group members asked her to teach the lessons on Christianity and Judaism because none of them wanted to teach those, for fear of coming across as biased. For her lesson on Judaism, Ann sought to "break down stereotypes". During her initial activity, Ann distributed to each student a card containing the name of a famous Jew, including actors, musicians, scientists, and politicians. After the students failed to identify what the people had in common, Ann told them; however, she was completely unprepared for their reactions, and she froze. The students were surprised that the people represented on the cards and several made naïve, nonetheless rude, comments. Admittedly, Ann did not know how to handle their comments and quickly transitioned to another activity without meeting her goal of breaking down stereotypes about Judaism.

During her lesson on Christianity, Ann accomplished her goal of "having [the students] pull out the information" since she "left it more up to the students' interpretation." Ann noted that her lessons "were structured differently than theirs. Their lessons were structured with a PowerPoint, and they presented, 'here is what they believe and their symbol.' Theirs were very straight forward." In contrast, Ann's lessons attempted to "bridge history and contemporary issues" by "allowing students to have more independent thinking."

\subsubsection{Beth}

Beth's group, unlike each of the others, took a thematic approach to teaching the five major world religions. In her lesson, Beth focused on the symbols, rituals, and documents that bind together people of a particular religion. She noted, "I wanted to break it down into the basic parts, to look at the main values, and parts, and books. I wanted to have the students try to notice patterns without us telling them - lead them to water."

In her lesson plan, Beth wrote that one of her objectives was to "[G]uide their interpretation of the influence of religion on cultural systems." In an attempt to illustrate this concept, Beth put up a political cartoon for students to analyze, reflect on, and then discuss. The cartoon contained a picture of one lady in a bikini and sunglasses looking at a lady wearing a burka. The lady in the bikini was thinking: "Everything covered but her eyes. What a cruel, maledominated culture." The lady in the burka was thinking: "Nothing covered but her eyes. What a cruel, male-dominated culture." All three of us researchers were in the classroom to observe Beth's lesson and were all astonished by how the students reacted to the cartoon. The classroom was completely silent for over five minutes as the students pondered the cartoon. The students' facial expressions and other body language indicated a mix of confusion, profundity, and revelation. Beth commented:

I was amazed at how the kids reacted to the cartoon. You could have heard a pin drop. It was like they had never thought of something like that before. It was the perfect springboard to our discussion about what is believed to be right or wrong, good or bad, fair or unfair. You could clearly tell that most of the kids had never thought like that before. 


\subsubsection{Deb}

Due to a variety of unforeseen factors, Deb's lesson on Confucianism was allotted less than 30 minutes, which was 20 minutes shorter than she had planned. Deb wanted the students to wrestle with some higher-order thinking skills questions (HOTS) related to some quotes from Confucius: "I wanted the kids to draw their own conclusions and to think of their own ideas behind the quotes." She wanted students to understand how Confucianism still influences Chinese society today. Admittedly, her lesson did not go very well: "I kind of bombed. I didn't have enough time, and the students were stumped by the HOTS questions." Her intent was to engage students in critical thinking, but she conceded, "[B]ecause I didn't have as much time as planned, I should have just given them some key concepts.

\subsubsection{Christine}

Christine's group chose at random the religion each would teach; and, because the four group members were assigned to teach five religions, Christine drew two: Christianity and Hinduism. For her lesson on Christianity, Christine wanted to illustrate how modern US culture is replete with Christian symbolism. She planned to use examples of Christianity's symbolism (eg: the cross, statues, stained glass) and traditions (Pledge of Allegiance, swearing on bible, holidays, songs) to set-up a review of Christianity's origins and diffusion. Christine noted that she had anticipated students' Christian bias, but she was still taken aback by how hard it was for the students to be objective. She commented:

\section{While I was teaching Christianity, the students kept bringing up their own beliefs and opinions, so then I would try to get} them back to the facts and the history behind it, but it was hard. They had so much to say.

In contrast, Christine's lesson on Hinduism was met with little reaction from the students, other than immature comments like, "So, like, if I'm a bad kid and die tomorrow, will I come back as a mosquito?"

Christine began her lesson around the history and background of Hinduism in a teacher-centered fashion, which the students responded to passively. Next, she transitioned to a student-centered activity on the concept of Moksha, where students read documents and answered questions at the following stations: Jnana yoga (path of knowledge and wisdom, Karma yoga (path of action and selfless service), Bhakit yoga (path of devotion), and Raja yoga (path of selfcontrol and self-mastery. The students were engaged during this activity, though many struggled to make the requested connections between these concepts and their lives today. When Christine began to teach about reincarnation, however, the students began to act silly. Christine reflected:

I guess it was just too hard for them to get their heads around the idea. I'm not really sure what I could have done differently though. It's such a hard concept to teach, especially because I don't get it either.

\subsection{Future Classrooms}

After asking the four PSTs to reflect on their weeklong experience teaching world religions, we challenging them to forecast how their non-religiousness would impact their future teaching, in general and related to the teaching of world religions. All four PSTs recognized that their views would be different from the vast majority of their colleagues' and students'; and consequently, three of the PSTs would be hesitant to let anyone know that they were A/A. For example, Christine commented, "It'd be scary. Parents might get mad. I could lose my job. Kids might twist my words around and parents would get more mad, and then I might not be able to get other jobs because of it." Only Beth would be willing to let her colleagues or students know she doesn't believe in God, stating: "I don't plan to just tell people I'm atheist, but if someone asks, I won't shy away from telling them."

Consistent with their passivity toward friends and acquaintances who are religious, the PSTs were not concerned about teaching in schools where the majority of students and staff are religious. For example, we asked the PSTs about a recent state law that will require teachers to lead their students in the recitation of the Pledge of Allegiance at the start of every school day. None of the PSTs objected to saying "under god". For example, Deb said, "I would probably say it, and it would not bother me. Actually, I wouldn't think twice about it." Ann was quite introspective: "I would say the Pledge, because the Pledge has a purpose other than the specific words." We also asked the PSTs if they would take a job at a parochial school, and all but Beth said they would. Deb, who had attended a Catholic school, said, "I might have to lead a prayer, and that does not bother me." 


\title{
4.6 Critical Thinking
}

In general, the four PSTs conveyed a desire to teach kids to be critical thinkers and to be open-minded. Beth explained her planned approach to teaching like this:

\begin{abstract}
Something I always think about is how I want to teach kids to love to learn and teach them to think. I want them to want to learn how to find things. I want to teach them to want to ask questions and be critical. I think it does tie in with my atheism as far as reason and questioning and logic. [Students] do need to know how to look at a problem and figure out how to solve it in different ways.
\end{abstract}

Ann expressed her teaching philosophy succinctly: "I think the purpose of education is to create independent thinkers." Christine also noted her goal to "present subjects that have students really focus on their critical thinking skills to they can apply them;" however, she revealed concern about offending students' parents: "As a public school teacher, I don't think it's my job to sway them from their parents' beliefs, so l'd have to be careful about teaching some things." Despite her repeated goal of teaching students to think critically, Ann also acknowledged her hesitation to offend: "I'm very open minded and receptive, but at the same time if there is any controversial debate or discussion, I would be more inclined to say this is not the right place and time to have this conversation."

The A/A PSTs consistently emphasized their desire to provide students with multiple perspectives. For example, Christine said,

I would try to teach my students, 'this is what the textbook says', and let them know what other people believe and tell them, 'this is what some believe but others believe this.' I will be careful in the way I write my questions. Depending on what grade they are in, I can't change their mind, but I can let them know the different sides.

Deb expressed a similar projection about her future teaching: "I do think my classroom will be a lot of grey. I think kids deserve to form their own opinions and figure out things on their own and draw their own conclusions."

The A/A PSTs addressed how their experiences with having views that were different from the majority influenced their philosophies about teaching. For example, Ann recalled, "I've been stereotyped and discriminated against, so I will be more open-minded in my teaching because of that." Deb's explained why she is an advocate for valuing multiple perspectives:

I think I am open and would let kids come to their own conclusions about the world. I'm not outspoken enough to push my conclusions on others because I know what that feels like because I've had people push their views on me.

Although the A/A PSTs clearly asserted that their future teaching would emphasize critical thinking and openmindedness, it is not clear the extent to which this ambition is impacted by their lack of religion or how their teaching goals differ from their classmates'. The PSTs suggested that that compared to their classmates, they were more likely to engage students in controversy and debate. For example, Beth stated, "I think my classmates would completely avoid talking about many current events and conflicts because they are afraid of kids and parents getting upset.

\section{Discussion}

A/As tend to emphasize rationality and evidence-based thinking (Smith, 2013), and the four A/A PSTs in this study seemed to match that assertion. They frequently mentioned how they would like to employ critical thinking tasks in their future classrooms. Teachers' epistemological beliefs -- beliefs about the nature of knowledge -- impact how they teach and are part of their self-identity (Beijaard et al., 2004; Pajares 1992). The A/A PSTs desire to teach in ways that prompt students to be skeptical and to demand evidence for claims. Yet, despite their desire to teach using progressive methods, the A/A PSTs do not intend to resist the ubiquity of religion in schools. In fact, they were quite indifferent about reach of religion in schools.

Christianity plays a dominant role in American culture, and Christian teachers are typically public about their religious identities (White, 2009). Teachers whose identities do not align with the norms of the school culture often experience distress (Britzman, 2006), and develop a "disgruntled sense that they must play the part convincingly to fit in better with their established colleagues ... to portray the teacher "look"' (Howard \& Lloyd, 2013, p. 39).

Identity is linked to agency, which relates to teachers' beliefs that they have the ability to influence their students' lives (Lasky, 2005). Teacher agency is shaped by and shapes the school context and culture. Although teachers possess the ability to influence their students, their agency is mediated by the cultural norms of the school. Lasky (2005) described how teachers can experience vulnerability when they "feel they are being 'forced' to act in ways that are inconsistent with their core beliefs and values" (p. 901). The participants' vulnerability was revealed by their indifference 
regarding saying "under God" in the Pledge of Allegiance. The participants were so enculturated into the Christiandominant milieu of public schools that they willingly went along with practices that conflict with their values.

Arguably, the A/A PSTs lacked agency because they did not exercise judgment on behalf of their convictions. The four A/A PSTs felt helpless to alter the Christian-dominant culture of our public schools. Teachers' agency is mediated by their self-efficacy, and lack of agency is often associated with stress and anxiety (Bandura, 1993; Pajares, 1997). When teachers feel pressured to act in ways that run counter to their self-identities, particularly when their values conflict with the norms of the school, their self-efficacy is impacted (Cooper \& Olsen, 1996). What's more, early-career teachers face additional constraints and a reduced sense of agency (MacLure, 1993; Nias, 1996, which contributes to teachers leaving the profession early in their careers (Beltman, Mansfield, \& Price, 2011).

Healthy relationships with colleagues and other members of the school community can serve as protective factors against teacher burnout (Beltman, et al., 2011, Hong, 2010; Marvel, et al., 2007). It is likely that A/A teachers are more isolated than the average teacher and might not have supportive and earnest personal conversations with their colleagues because of their religious differences (Bramlett, 2012; Smith, 2013). Stigmatized individuals or groups tend to have lower self-esteem than those in the dominant group (Leary, Tambor, Terday, \& Downs, 1995); therefore, A/A teachers are likely to lack some of the protective factors against stress, burnout, and attrition (Beltman, et al., 2011).

Teacher quality is by far the most influential school-related factor on student growth and achievement. Few would question the notion that quality teachers facilitate critical and evidence-based thinking. If we are to assume that the selfidentities of A/A teachers relate to their professional identities, whereby they have a propensity to be skeptical and demand evidence, it follows that A/A teachers would prioritize teaching that emphasizes the "intellectually disciplined process of actively and skillfully conceptualizing, applying, analyzing, synthesizing, and/or evaluating information gathered from, or generated by, observation, experience, reflection, reasoning, or communication, as a guide to belief and action" (Scriven \& Paul, 1987, ๆ 4).

Our schools need teachers who will teach like this. We need to attract those types of teachers to the profession and we need to retain them. Because teacher retention and professional stability is highly dependent upon teachers having a secure and well-understood professional identity (Beijaard et al., 2004), as well as a supportive professional community, we need to consider ways to support A/A teachers.

\section{References}

Association of Religion Data Archives (ARDA). The Lord's Prayer in Public Schools, Retrieved Sep 30, 2013 from http://www.thearda.com/QuickStats/qs_108.asp

Baker, J. O. B., \& Smith, B. (2009). None too simple: Examining issues of religious nonbelief and nonbelonging in the United States. Journal for the Scientific Study of Religion, 48(4), 719-733.

Ball, S. J., \& Goodson, I. F. (1985). Understanding teachers: Concepts and contexts. In S. Ball and I. Goodson (eds). Teachers' lives and careers. London: Falmer, pp. 1-26.

Bandura, A. (1993). Perceived self-efficacy in cognitive development and functioning. Educational psychologist, 28(2), 117-148.

Becker, H. S. (1963). Outsiders: Studies in the sociology of deviance. New York: The Free Press of Glencoe.

Beijaard, D., Meijer, P. C., \& Verloop, N. (2004). Reconsidering research on teachers' professional identity. Teaching and teacher education, 20(2), 107-128.

Beltman, S., Mansfield, C. \& Price, A. (2011) Thriving not just surviving: A review of research on teacher resilience. Educational Research Review, 6(3). pp. 185-207.

Bramlett, D. M. (2012). Godless Americans: How non-religious persons are labeled as deviant in a religious society. (Master's thesis). Retrieved from http://scholarworks.sjsu.edu/etd theses/4224/

Britzman, D. P. (2006) Foreword. In J. Alsup, Teacher identity discourses: Negotiating personal and professional spaces (pp. ix-xvi). New Jersey: Lawrence Erlbaum Associates Inc.

Charmaz, K. (2006). Constructing grounded theory: A practical guide through qualitative analysis. London: Sage.

Cimino, R., \& Smith, C. (2007). Secular Humanism and Atheism beyond Progressive Secularism. Sociology of Religion, 68(4), 407-424.

Cline, A. (2006, March 30). Atheists discriminated against in child custody cases. Retrieved September 23, 2013 from http://atheism.about.com/b/2006/03/30/atheists-discriminated-against-in-child-custody-cases.htm

Cohen, L., Manion, L., \& Morrison, K. (2011). Research methods in education. London: Routledge.

Coldron, J., \& Smith, R. (1999). Active location in teachers' construction of their professional identities. Journal of curriculum studies, 31(6), 711-726.

Cooper, K. \& Olson, M. (1996) The multiple 'I's' of teacher identity. In M. Kompf, T. Boak, W. R. Bond \& D. Dworet (Eds) Changing research and practice: teachers' professionalism, identities and knowledge (London, Falmer Press).

Cragun, R. T., Kosmin, B., Keysar, A., Hammer, J. H., \& Nielsen, M. (2012). On the Receiving End: Discrimination toward the Non-Religious in the United States. Journal of Contemporary Religion, 27(1), 105-127.

Edgell, P., Gerteis, J., \& Hartmann, D. (2006). Atheists as "other": Moral boundaries and cultural membership in American society. American Sociological Review, 71(2), 211-234.

Feagin, J. R. \& Feagin, C. B. (1978). Discrimination American style: Institutional racism and sexism. New York, NY: Prentice-Hall.

Galen, L. W. (2009). Profiles of the godless: Results from a survey of the non-religious. Free Inquiry, 29, 41-45. 
Glaser, B., \& Strauss, A. (1967). The Discovery of Grounded Theory. Chicago: Aldine.

Hammer, J. H., Cragun, R. T., Hwang, K., \& Smith, J. M. (2012). Forms, frequency, and correlates of perceived anti-atheist discrimination. Secularism and Nonreligion, 1, $43-67$.

Hartwick, J. M. (2012). An overview of an emerging area of research into the religious and spiritual lives of public school teachers. International Handbook of Protestant Education, 6(7), 663-677. DOI:10.1007/978-94-007-2387-0 37

Hartwick, J. M. M. (2009). Public school teachers' beliefs in and conceptions of God: What do teachers believe, and why it matters? Paper presented at the AERA 2009, Annual Meeting, San Diego, CA.

Hartwick, J. M. M. (2007). The religious and prayer lives of public schoo teachers. Christianity, Education, and Modern Society. Greenwich, CT: Information Age Publishing.

Hong, J. Y. (2010). Pre-service and beginning teachers' professional identity and its relation to dropping out of the profession. Teaching and teacher Education, 26(8), 1530-1543

Hooper, S. (2006, Nov 9). The rise of the 'new atheists'. Retrieved from: http://www.cnn.com/2006/WORLD/europe/11/08/atheism.feature/index.html

Howard, T. K., \& Lloyd, R. (2013). To feel a look, to see the flesh: Phenomenological reflections of a pierced and tattooed pre-service teacher. Cultural and Pedagogical Inquiry, 4(2).

Jacoby, S. (2004). Freethinkers: A history of American secularism. New York, NY: Metropolitan.

Johnson, K. A. (2003). "Every experience is a moving force": identity and growth through mentoring. Teaching and teacher education, 19(8), 787-800.

Kelchtermans, G. (2009). Who I am in how I teach is the message: Self-understanding, vulnerability and reflection. Teachers and Teaching: Theory and practice, 15(2), 257-272.a

Kimball, M. S., Mitchell, C. M., Thornton, A. D., \& Young-Demarco, L. C. (2009). Empirics on the origins of preferences: The case of college major and religiosity (No. w15182). National Bureau of Economic Research.

Kleiman, S. (2004). Phenomenology: To wonder and search for meanings. Nurse Researcher, 11(4), 7-19.

Lasky, S. (2005). A sociocultural approach to understanding teacher identity, agency and professional vulnerability in a context of secondary school reform. Teaching and teacher education, 21(8), 899-916.

Leary, M. R., Tambor, E. S., Terdal, S. K., \& Downs, D. L. (1995). Self-esteem as an interpersonal monitor: The sociometer hypothesis. Journal of Personality and Social Psychology, 68, 518-530.

MacLure, M. (1993) Arguing for your self: identity as an organising principle in teachers' jobs and lives, British Educational Research Journal, 19(4), 311-322.

Marvel, J., Lyter, D. M., Peltola, P., Strizek, G. A., Morton, B. A., \& Rowland, R. (2007). Teacher Attrition and Mobility: Results from the 2004-05 Teacher Follow-Up Survey. NCES 2007-307. National Center for Education Statistics, 63.

Miovic, M. (2004). An introduction to spiritual psychology: Overview of the literature, east and west. Harvard Review of Psychiatry, 12(2), 105-115. doi:10.1080/10673220490447209

Nias, J. (1985). Reference groups in primary teaching: Talking, listening and identity. In S. J. Ball, \& I. Goodson (Eds.), Teachers' lives and careers, 105-119. London: Falmer Press.

Nias, J. (1996) Thinking about feeling: the emotions in teaching, Cambridge Journal of Education, 26(3), 293-306.

Pajares, F. (1997). Current directions in self-efficacy research. Advances in motivation and achievement, 10(149). 21-40

Pajares, M. F. (1992). Teachers' beliefs and educational research: Cleaning up a messy construct. Review of educational research, 62(3), 307-332.

Pew Research Center. (2012). "Nones" on the rise: One-in-five adults have no religious affiliation. Retrieved from http://uww.pewforum.org/2012/10/09/nones-on-the-rise/

Plante, T. G. (2010). The Santa Clara Strength of Religious Faith Questionnaire: Assessing faith engagement in a brief and nondenominational manner. Religions, 1(1), 3-8.

Plante, T. G., \& Boccaccini, M. T. (1997). The Santa Clara strength of religious faith questionnaire. Pastoral Psychology, 45(5), 375-387. DOI:10.1007/BF02230993

Reynolds, C. (1996) Cultural scripts for teachers: identities and their relation to workplace landscapes, in: M. Kompf, T. Boak, W. R. Bond \& D. Dworet (Eds) Changing research and practice: teachers' professionalism, identities and knowledge (London, Falmer Press).

Ribak-Rosenthal, N., \& Kane, C. M. (1999). Minority religious practices: The need for awareness and knowledge. Counseling and Values, 43(2), 142-152

Savage, D. G. (2013, August 8). Obama administration backs prayer at local government meetings. Los Angeles Times. Retrieved from http://www.latimes.com/news/nationworld/nation/la-na-court-prayer-20130809,0,6470966.story

Scriven, M., \& Paul, R.. (1987). A statement presented at the $8^{\text {th }}$ Annual International Conference on Critical Thinking and Education Reform, Summer 1987. Retrieved Oct 4, 2013 from http://www.criticalthinking.org/pages/defining-critical-thinking/766

Sherman, Rob. Documents at Bush Presidential Library ProveVP Bush Questioned Citizenship and Patriotism of Atheists. Retrieved September 22 , 2013 from http://www.robsherman.com/advocacy/060401a.htm

Slater, R. O. (2008). American Teachers: What Do They Believe?. Education Digest: Essential Readings Condensed for Quick Review, 73(9), 47-51.

Smith, G. H. (1979). Atheism: The case against god. Buffalo, N.Y.: Prometheus Books.

Smith, J. M. (2013). Creating a Godless Community: The Collective Identity Work of Contemporary American Atheists. Journal for the Scientific Study of Religion, 52(1), 80-99.

Stake, R. E. (1995). The Art of Case Study Research. Thousand Oaks, CA: Sage.

Stedman, C. (2012, December 12). In wake of Newtown shooting, why blame atheists? Retrieved from http://tv.msnbc.com/2012/12/27/in-wake-ofnewtown-shooting-why-blame-atheists/

Sutherland, L., Howard, S., \& Markauskaite, L. (2010). Professional identity creation: Examining the development of beginning preservice teachers' understanding of their work as teachers. Teaching and teacher education, 26(3), 455-465.

Wenger, E. (1998). Communities of practice: Learning, meaning, and identity. Cambridge university press.

White, K. R. (2009). Connecting religion and teacher identity: The unexplored relationship between teachers and religion in public schools. Teaching and Teacher Education, 25(6), 857-866.

Yin, R. K. (1994). Case study research: Design and methods. Thousand Oaks, CA: Sage Publications. 